\title{
EROSION AND SEDIMENTATION IN CHESAPEAKE BAY AROUND THE MOUTH OF CHOPTANK RIVER.
}

\author{
By J. Fred. Hunter. \\ INTRODUCTION.
}

With the unfolding of geologic knowledge during the last century the processes of denudation, transportation of sediments, and sedimentation have become better understood, and to some extent their relative effects in bringing about the present configuration of the earth's surface have been determined. The nature of these processes has been studied in many parts of the globe, but owing to the large size of the units affected and the slowness of the processes there has been little opportunity to collect quantitative data. Indeed, the data available are very largely conjectural, their degree of accuracy being only that of good guessing. However, with the advent of accurate topographic and hydrographic surveys, the first steps toward actual measurements of some of the many interesting surficial changes that are in progress have been taken, and it only remains for time and additional observations to afford opportunities for comparison. Resurveys, particularly by the United States Coast and Geodetic Survey, of parts of the eastern coast of the United States at different intervals have shown in many places marked changes of both shore line and sea bottom, as on Cape Cod, on Nantucket Island, and in Delaware Bay. Comparisons of this kind have so far been incidental to work in engineering and coast surveying, so that there has been little opportunity for the selection of localities particularly adapted to studies of erosion and sedimentation.

Chesapeake Bay, which is really a large tidal river, is favorable for such investigations, in that it has a drainage basin of moderate size and retains a large part of the sediments brought in from that basin by its tributary rivers. Moreover, this bay, since the memorable explorations of Capt. John "Smith in 1608, has been of much interest to explorers and map makers. The classic map made by Smith was followed by many others of varied character, such as Herman's "Map of Virginia and Maryland" (1670) and Griffith's "Map of Maryland" (1794), both of which were the standard maps of their time and marked great advances in the cartographic knowledge of the bay. ${ }^{1}$ In the course of the general economic development of this region further data as to the limits and character of Chesapeake Bay and its tributaries continued to accumulate as the result of the work both of governmental bureaus and of private concerns until in the fourth decade of the last century the need began to be felt for a thorough topographic and hydrographic study of the bay. In 1845 the United States Coast and Geodetic Survey began such a study, and by 1848 had surveyed the entire bay and prepared charts on the scale of 1:20,000 showing with accuracy the shore lines and the depths of water. In 1900 it was deemed necessary to make a similar study of the bay in connection with the work of the Maryland Shell Fish Commission, and by 1903 a second set of charts had been completed by the Coast Survey, on the same scale and showing the same detail as the earlier charts. Both sets of charts are accurate and are unique in covering so well so large and important an area at dates removed from each other

\footnotetext{
1 For an interesting detailed history of the explorations and surveys of Chesapeake Bay, see Mathews, E. B., The maps and map makers of Maryland; Maryland Geol. Survey. vol. 2, pt. 3, 1898.
} 
by an interval of more than half a century. Even a cursory examination of the corresponding charts of the two periods shows important changes in the position of the shore line and of the bay bottom.

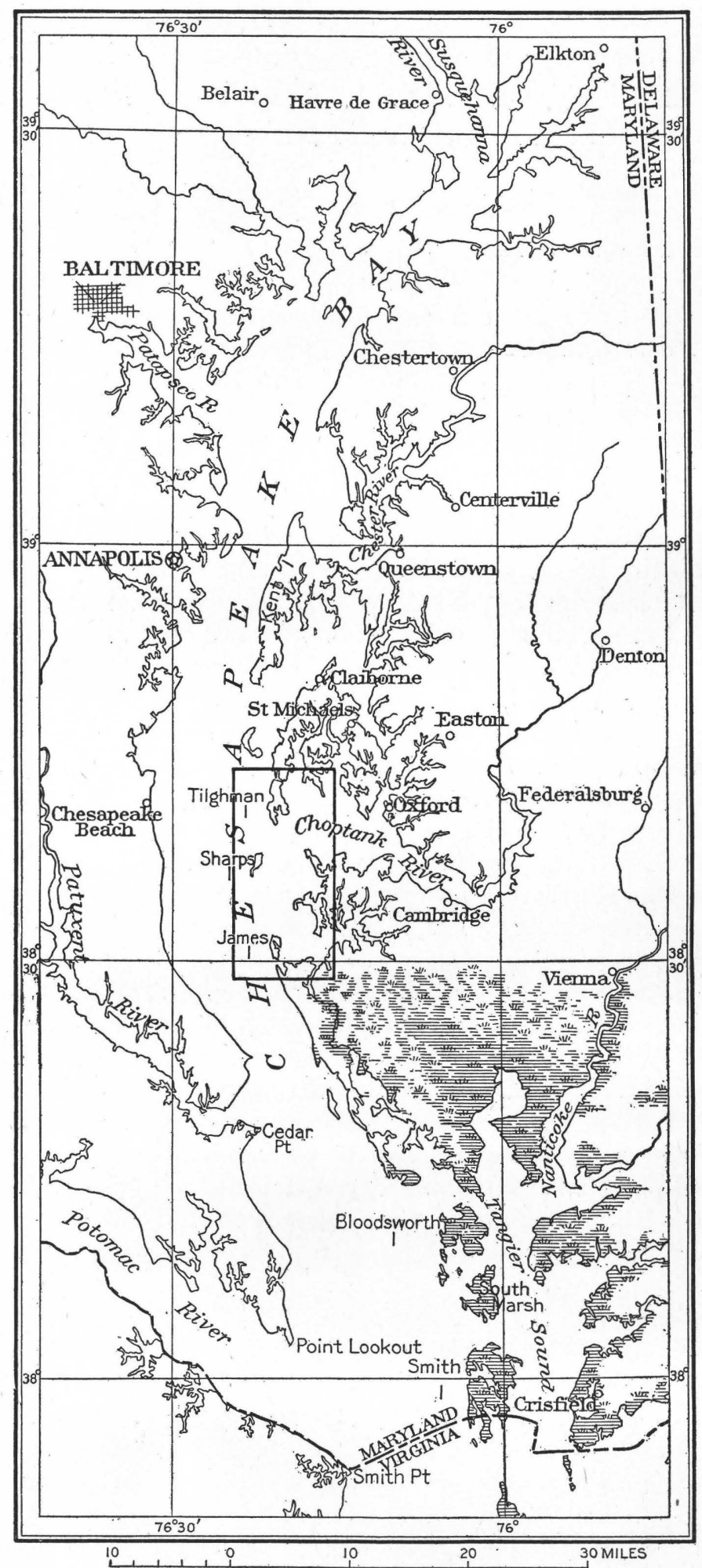

FIGURE 1.-Sketch map of Chesapeake Bay, showing the area studied and its relation to other parts of the bay.
Mr. Charles Yates, of the United States Coast and Geodetic Survey, who has spent a number of years on Government survey work in Chesapeake Bay and to whom the writer is indebted for a number of facts used in the preparation of this paper, has repeatedly urged a study of the processes of erosion and sedimentation as brought out by a comparison of these charts. Owing to the great mechanical labor and the long time necessary for such an investigation, the writer has contented himself with the study of a very small test area on the eastern shore of the bay around the mouth of Choptank River, including Tilghman, Sharps, and James islands and the adjacent mainland, with the purpose of ascertaining the advisability and possible results of a more elaborate study of the entire bay. (See fig. 1.) The test area, which is situated about midway of the length of the bay, is representative of that portion of it which has suffered change sufficient to be noted by cursory examination of the two sets of charts. Moreover, it lies in an intermediate position, north of which the change in shore lines has been effected chiefly by erosion and south of which there has been a very large amount of marsh building. This small area affords an excellent opportunity to establish certain local rates of erosion and sedimentation, but of course gives no data for many of the larger and more general conclusions that would be expected from a study of the entire bay. For example, the relation of sedimentation to land waste as studied by Humphreys and Abbot in the Mississippi River basin and by Mellard Reade, Élie de Beaumont, Archibald Geikie, and others in river basins of Europe and elsewhere, suggests itself as a subject for an investigation that could hope to bear fruit only if pursued on the larger scale. 


\section{SURVEYS OF THE AREA DISCUSSED.}

The earliest adequate sketch of the mouth of Choptank River is on Herman's "Map of Virginia and Maryland" (1670). Although the map shows much distortion, the chief land features of the area here discussed are represented about as they exist to-day except that James Island (called James Point) had a broad connection with the mainland. Griffith's "Map of Maryland" (1794) shows the land features as they are now, James Island, strange to say, being widely separated from the mainland, although a chart of the Coast Survey prepared in 1848 shows a narrow isthmus between the two. A singular though probably not very significant fact in view of the primitive methods of surveying and the moderate degree of accuracy of the two early maps is that on each of them Tilghman Island is represented as having an outline very different from its present shape and as being separated from Sharps Island by a considerable stretch of water. This fact is interesting in view of the current belief of the inhabitants in a very recent land connection between the two islands. Although these maps are of interest in view of the changes that are known to be taking place, no reliance can be put on their accuracy.

Besides the topographic and hydrographic surveys of 1847-48 and 1900-1901, a plane-table survey, of the shore lines of James and Sharps islands, the southern portion of Tilghman Island, and Cook and Hills points was made by Mr. Yates and the writer in December, 1910, with the aid of the charts and triangulation stations of the Coast and Geodetic Survey. The United States Geological Survey has published topographic and geologic maps covering the area, ${ }^{1}$ which is located partly in the Choptank and partly in the St. Marys quadrangle.

\section{TOPOGRAPHY AND GEOLOGY.}

Two principal topographic and geologic features are represented in this area. One of these is the plain or terrace occupied by the Talbot formation, which is the lowermost and at the same time the youngest of the Pleistocene Columbia group. Although elsewhere this terrace may rise to 40 feet above sea level, it does not reach more than 10 feet in the area under discussion. It is built up chiefly of clay marl and sand, with scattered patches of gravel, and in most places it is terminated by a low scarp cut by the waves, though locally it slopes gently to the water's edge. The other principal feature is the tidal marshes which occupy the remaining but much smaller part of the area not covered by the Talbot formation. They consist of low-lying, swampy land which at high tide may be largely submerged. They are composed mainly of the same materials as the Talbot but contain also an abundant growth of swampy sedge or grass which aids in filling up the depressions by serving as obstructions that retain the mud and by furnishing a perennial accumulation of vegetable débris. The living and dead plants form a thick network through the clay marl and peat, which, thus reinforced at the water's edge, offer great resistance to the cutting of the waves.

\section{CHANGES IN SHORE LINE. JAMES ISLAND.}

Loss in area.-James Island is the southernmost of the trio of islands (James, Sharp, and Tilghman islands) which stand in a line across the mouths of Choptank and Little Choptank rivers and front on the bay. It is crudely wedge-shaped and is nearly cut in two by an inlet that crosses it diagonally. It is next to Tilghman Island in size, being nearly 2 miles long and three-quarters of a mile wide and having a present area of 490 acres. Although now deserted except for a few families the island had at one time a much larger population, as shown by the presence of about 20 houses, a schoolhouse, and a church. The land nowhere rises above 10 feet in elevation, and the shore scarps in places attain 7 feet.

A comparison of the maps of 1848 and 1900 shows some remarkable changes in this island. (See Pl. III.) The narrow isthmus, probably no more than a sand bar, which connected the island with the mainland in 1848 had disappeared in 1900, when 0.28 mile of water separated the two land bodies. At the time of the survey in 1900 the west shore had receded to a point

1 Shattuck, G. B., and Miller, B. L., U. S. Geol. Survey Geol. Atlas, St. Marys folio (No. 136), 1906. Miller, B. L., U. S. Geol. Survey Geol. Atlas, Choptank folio (No. 182), 1912. 
500 yards beyond the head of the inlet of 1848. The inlet had been filled in and the sand bar separating it from the bay had shifted bodily eastward. In area the island had decreased from 975 acres in 1848 to 555 acres in 1901. It had thus suffered a loss of 420 acres, or 43 per cent, in 53 years, showing a mean annual loss of nearly 8 acres. During the succeeding 9 years it was cut down to 490 acres, an average of over 7 acres being cut away each year, the total loss for the period being 65 acres, or 12 per cent. During the 62 years covered by the study, 485 acres, or nearly half the island, had disappeared, an average of 7.8 acres, or about 0.8 per cent of the original area, being carried away each year. However, as the island becomes smaller and the coast line shorter, this average annual loss will be reduced.

Linear cutting.-As in the other islands, almost the entire cutting has taken place on the northern and western shores, the eastern strand line remaining practically stationary during the entire period. The cutting of the outer shores is doubtless due to the strong bay currents and storm waves which sweep these shores, eroding and carrying away great quantities of sediment. However, the rate of cutting has differed notably in different parts of the shores, owing in large measure to unequal resistance of the land material. In general, where the land is comparatively high and where the shore material consists of the clays and marls of the Talbot formation, the cutting goes on most rapidly. In such places the low cliffs offer favorable conditions for erosion. The marly clay, being undercut by the waves, crumbles down in clods or lumps of various sizes. This process of breaking down is helped and to some extent regulated by joints and narrow clay seams, probably formed by the percolation of water dashed back on shore. In many places the shore has numerous angular and rounded reentrants, in some of which are fashioned small caves that may extend to a distance of several feet. The presence of trees on the shore, especially where it is high, may hasten the retreat of the strand line. As the waves cut away the earth from around their roots they fall over into the water, carrying a quantity of soil with them and loosening still more of it where they formerly stood.

The low-lying marl land is much more resistant to erosion than the higher clay scarps. The salt marshes formed by this type of shore deposit support a dense growth of sedge and grass, whose roots are matted together in the clay and sand. This vegetation serves to hold the fine material blown and washed over it, and the marsh is thus built up. At the same time the waves are unable to cut this reinforced material rapidly. Out of these facts comes the explanation of a rather curious and interesting phenomenon. The map of 1901 showed that the only remains of the north end of the James Island of 1848 was a small island situated on the spot which was formerly an arm of the diagonal inlet but which was later filled with marsh material. That water in the midst of land in 1848 should become land in the midst of water in 1901 is a remarkable result of the greater resistance of the marsh-built land. Similar phenomena have been noted elsewhere in the course of the study; in fact, wherever the shore has been of tide-marsh formation the erosion has been comparatively slight.

Another interesting feature of the change in James Island is the shifting of the sand bar that separates the waters of the bay from the head of the inlet. The waves probably add about as much sand as they carry away, the accretions being largely carried over into the inlet basin. Thus the bar seems to be moving slowly eastward. It is probable that in time the bar will be broken through, as was the bar between the island and the mainland. Once open the channel would be widened and the rate of erosion of the resulting two islands accelerated.

No less striking than the loss in area suffered by the island during the last 62 years is the amount of linear advance of the bay. A comparison of the first two maps shows that the average amount of erosion on the north and west coasts of the island during the period from 1848 to 1901 was nearly a quarter of a mile and the annual average was 24 feet. That the rate is fairly constant is shown by the fact that during the nine years succeeding 1901 the average annual rate was 23 feet. At this rate the island, whose maximum width is 0.66 mile, should disappear in about 150 years. This estimate is almost exactly the same as another reached by a consideration of the annual areal loss per mile of eroded shore line. Although this agreement is interesting, the result is little more than a guess, as numerous other factors may enter to disturb the present conditions and rate of erosion. 


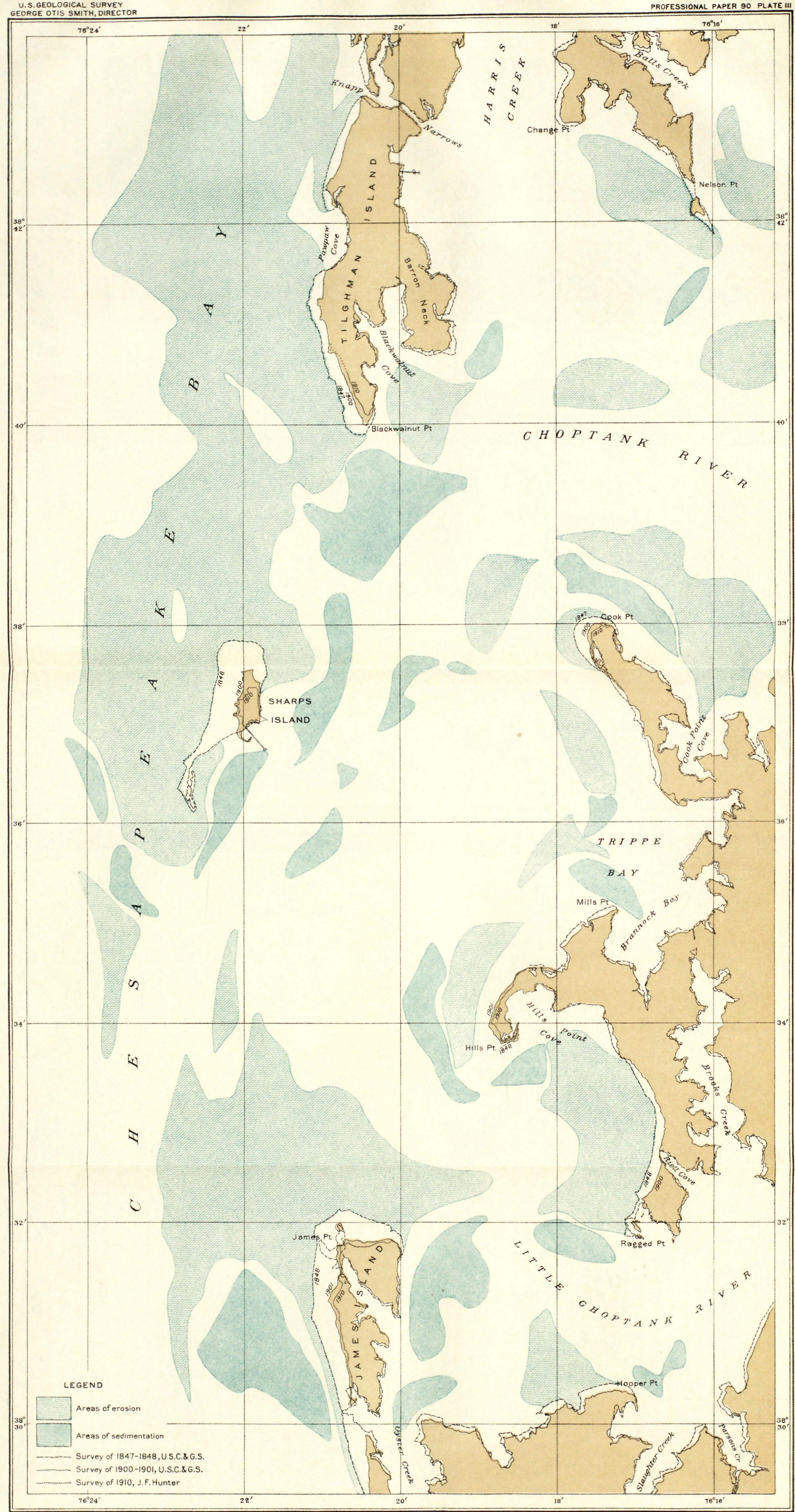

MAP OF THE MOUTH OF CHOPTANK RIVER, WITH TILGHMAN, SHARPS, AND JAMES ISLANDS Showing positions of the shore line at the time of different surveys, together with areas of erosion and se

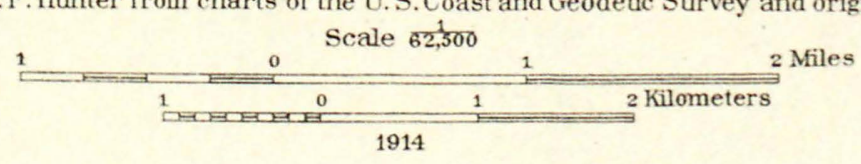




\section{SHARPS ISLAND.}

Loss in area.- Sharps Island, the smallest of the three under discussion, stands directly at the mouth of Choptank River, unprotected on any side from the action of the waves. Less than a generation ago it was a summer resort and supported a number of people throughout the year. The north end was well wooded and the island was a favorite ground for hunting ducks and small game. The days of its prosperity are now but a memory, and the life of the island is a thing of the past. The trees have disappeared save for a meager half dozen; the houses have been washed away except for the large hotel which stands alone in the center of the island, a crumbling monument to the activity of other days; the site of an artesian well has been transgressed by the waves so that it now presents the unique feature of a well in the midst of the waters of the bay. The survivors of the piling that made up the long pier which formerly invited the voyager only add to the melancholy of the deserted and dreary scene.

Impressions and hearsay are not the only evidence of remarkable changes in the island, for the story told by comparison of the three maps of 1848, 1900, and 1910 is equally noteworthy. In 1848 the island contained 438 acres; in 1900 the surprisingly small area of 91 acres, or but 21 per cent, had survived. There had been an average annual loss of 6.7 acres, or 1.5 per cent. Owing to the decrease in the length of shore line the amount of erosion annually during the period from 1900 to 1910 dropped to an average of 3.8 acres, which, however, was 4 per cent of the total area of 1900 . The area of the island in 1910 was 53 acres, showing a loss of 88 per cent in 62 years, an average annual loss of 6.2 acres, or 1.4 per cent.

Linear cutting.-The maximum erosion on Sharps Island, as on James Island, has been on the west and north sides, the east and south sides having remained substantially unchanged. An interesting feature is the continuance of the sand spit on the south end until after 1900, when the pier was washed away. Since then the spit has moved around to the southeast corner of the island, inclosing a small pond. The northern part of the island is made up of material of the Talbot formation and rises out of the water as much as 7 feet. Here the erosion has been enormous, the water advancing 0.35 mile in 52 years and 0.57 mile in 62 years. The average encroachment on the north and west coasts during the 52-year interval was 0.32 mile, or at the rate of 32 feet a year. During the 10 years between 1900 and 1910 the bay advanced 0.21 mile on the north shore, or at the remarkable rate of 110 feet a year. The loss on the west coast, however, was much less, averaging about 21 feet a year during the period.

The marshland of the southern part of the island is withstanding the force of the waves much more effectively than the rest of the island and will doubtless be the last to disappear. It may be interesting in this connection to venture a prediction, based on the facts at hand, as to the time of final disappearance of the island. By platting the length of the island as ordinates against the time interval between surveys, it is evident that the rate of erosion has greatly increased in the last 10 years. If the rate of that interval were to continue the island would disappear before 1930. However, it is obvious from the general study that the erosion was unusually intense during this period and furthermore that when the marshland is reached the rate will decrease. On the basis of the rate of encroachment during the 52-year interval and the maximum width of 0.28 mile, the time of disappearance would be put at 1947 . From a consideration of the annual areal loss per mile of shore line subject to erosion, one-half the remaining exposed shore line being used as a basis, the average annual loss will be 1.67 acres. By this method the date of the island's entire submergence would be put at 1942. At the rate during the last 10 years on the west coast, the estimated date would be a little later, probably about 1950 to 1955 .

From general considerations the writer feels that it is fairly safe to predict that Sharps Island will be entirely gone by 1950 and that it is not beyond the range of possibility that the island will disappear before 1940. The higher land to the north will doubtless be cut away first, and in 15 years, if the average yearly rate persists, the house will be reached. In 20 years probably little will be left but the low-lying marshland.

$$
37183^{\circ}-15-2
$$




\section{TILGHMAN ISLAND.}

Tilghman Island is the largest and most northerly of the three islands under discussion. It is over $3 \frac{1}{2}$ miles long and has an area of more than 3 square miles, providing homes for many prosperous farmers and fishermen. At its north end are located the towns of Tilghman and Avalon, with a population of several hundred people. It is separated from the mainland by a narrow strait called Knapp Narrows.

This island has suffered much less erosion in proportion to its area than either of the other two. The eastern coast, as in the other islands, remained essentially unchanged during the 63 years from 1847 to 1910 . Extensive erosion has taken place along the western coast, except in the protected portion in Pawpaw Cove, a semicircular indentation midway of the island.

During the 53 years between 1847 and 1900 the area of Tilghman Island decreased from 2,015 to 1,686 acres, a total loss of 329 acres, or over 16.3 per cent. The maximum encroachment of the sea has been on the southern cape (Blackwalnut Point), which has receded a quarter of a mile in 63 years. The average annual encroachment of the sea on the western shore during the 53-year period was 10 feet, the estimate excluding the shore of Pawpaw Cove, which has not changed. This is a much lower rate than those effective on the corresponding coasts of the other islands. Only the southern portion of the west coast was surveyed in 1910, but here the erosion has been rather rapid, averaging 29 feet a year for the 10-year period beginning with 1900 .

That Tilghman Island will have a much longer life than the other two islands is manifest. By considering as before the mean annual areal loss per mile of exposed shore line and using one-half the remaining westerly exposed shore line as a basis, it would seem that the island will not disappear in its watery grave for at least 570 years. However, this estimate must be regarded only as a very rough approximation.

Although the earliest maps show a large stretch of water between Tilghman and Sharps islands, many of the residents recount the tales told by their forbears of a generation or two ago concerning the proximity and even the connection of the two islands. It may be interesting in this connection to point out the fact that during the 63 years from 1847 to 1910 the average anmual widening of the intervening water area was 0.01 mile. As the islands in 1910 were 3.38 miles apart, the time of their separation, if this rate of widening has prevailed continuously, would be about 340 years ago, or about 1570. This is a hundred years earlier than the date of the oldest map, that of Herman, which shows a considerable stretch of intervening water.

\section{SHORES AROUND THE MOUTH OF THE CHOPTANK.}

This discussion so far has considered chiefly the shores exposed to the waves of Chesapeake Bay. It may be worth while for comparison to note the changes that have taken place on points affected more particularly by the currents of Choptank and Little Choptank rivers. Cook Point, which lies almost due east of Sharps Island, has been remarkably eroded. During the 53-year interval from 1847 to 1900 this point suffered a loss of 108 acres; or about 17 per cent of its area, thus losing about 2 acres each year. On the northwest coast of the point, where the erosion has been greatest, the water has encroached as much as 0.2 mile in 63 years, or at the rate of 16 feet a year. This rate, however, is a maximum-not an average for the coast line. An interesting feature is the increase of the rate during the 10 years from 1900 to 1910, when the maximum cutting amounted to 0.06 mile, or 32 feet a year. Except at the extreme end there has been comparatively little change on Cook Point. On the west side of the point a pond inclosed by a sand bar is filling up, and is a further example of strongly resisting marsh material. On Hills Point, south of Cook Point, there has been considerable erosion along the northwesterly exposed shores. The average rate here is about 15 feet annually, although the point of maximum cutting may show nearly twice that much. The spit at the end of this point is remarkable for its persistence throughout the 62 years. Farther south 
the west shore of Ragged Point was cut away to a distance of 0.14 mile in 52 years, or at the considerable rate of 14 feet a year. Nelson Point, on the north side of the Choptank and east. of Tilghman Island, suffered a very considerable loss in the 53-year interval before 1900 . The former point receded nearly a quarter of a mile, while farther north the neck was cut through by the currents, leaving the former southern part of the peninsula an island.

In general the erosion inside the rivers has been less than on the shores exposed to the action of the bay, although at a few favorable points the cutting has been equally great. As might be expected, the numerous inlets which in part make up the devious shore line of this area showed but little change at the end of the 53-year period. Except at the localities already mentioned, the shore does not show any large losses, the maximum probably being 300 or 400 feet. Moreover, nowhere in the area under discussion has any considerable amount of gain been made by the building up of land. However, south of the area studied large delta deposits are constantly growing and will add a very interesting chapter to the history of the bay.

\section{CHANGES IN SEL BOTTOM.}

\section{GENERAL STATEMENT.}

Comparison of the surveys of 1847-48 and 1900-1901 not only showed very appreciable changes in the position of the shore lines of the bay but also more or less shifting of the sediments on the sea bottom, as indicated by the differences in soundings for the two periods. Many of these differences are so slight as to come within he limit of error and of the personal equation of the hydrographers. At the same time, in the study of a large area such as the entire Chesapeake Bay, many of these small differences m ght rightly be taken into account, for any errors would probably tend to compensate rather than to accumulate. However, over a considerable area the results would without doubt be negative; that is, they would show no change. The area here discussed is entirely too $\$$ mall to obtain any very substantial or important conclusions. Nevertheless, a few facts may be worthy of note and may suggest further and better methods for the study of the larger problem.

The method here pursued was to draw, from the Coast Survey charts, hydrographic contours representing depths of $6,12,18$, and 30 feet be ow mean sea level for the two periods. By suitably designating the two sets of contours, the areas of cut and of fill could by a little inspection be distinguished. As an intermediate ster the area over which a recent contour had shifted was hachured differently according as it had moved toward what was higher ground, thus showing a scouring, or toward what was lower ground, thus showing a shoaling. This greatly facilitated the mapping of the areas subject to erosion and to sedimentation.

\section{AREAS OF EROSION.}

The largest and most important area of scouripg is that west of Tilghman and Sharps islands. In fact, except for a small area directly north of the mouth of Choptank River and an area west of James Island, the slopes of the bay have experjenced fairly uniform cutting. Almost everywhere, however, the erosion has been greatest near the shore, while at a depth of 30 feet the contours show but little change. In the vicinity of the 6 and 12 foot contours the difference in depth for the two dates very rarely reaches 6 feet, vhile the average would probably be much less.

Another area of extensive erosion is that north and west of James Island, at the mouths of Choptank and Little Choptank rivers, where there has been a deepening of more than 6 feet near shore and uniformly less toward the deep chinnel. An interesting and rather unexpected area of scour is that west of Ragged Point and southeast of Hills Point, but the amount of change here is somewhat smaller than in the other areas mentioned. Smaller areas of scour are scattered with little regularity over the region, the exact causal relations in many of them not being entirely evident. 


\section{AREAS OF DEPOSITION.}

The areas of deposition are fewer and somewhat more interesting than the areas of erosion. They indicate local checking of the movements of the currents, which may have resulted from a variety of causes. Perhaps the most interesting example of shoaling is that between Tilghman and Sharps islands, where more than 6 feet of sediment has been laid down in places, the maximum amount being found between the 12 and 18 foot contours. Here Choptank River, flowing westward, probably meets, for a large part of the time at least, a strong inshore current from the bay. The velocity of the river waters is thus diminished and deposition results. On the opposite (south) side of the channel scouring has taken place, thus indicating an acceleration of the river current on that side, except close to the shore, where, strange to say, the soundings show slight deposition. As the river flows on and reaches the broad stretch of water between Sharps Island and the shores of Trippe Bay, its velocity is again decreased, owing to the increase in area of cross section, with the result that deposition occurs on both sides of the channel.

North of the mouth of the river there is an area in which the movement of the water is modified, owing to the junction of the bay and river currents. Here there is, for this reason, a small area of deposition. The cause of the shoaling west of James Island is not immediately apparent, although it may lie in the diversion of the strong river current in a southeasterly direction by the bay currents, a portion of the water being thus backed up against the island and east of the main channel. Other areas of deposition are those east of James Island and on the east side of the Little Choptank between Ragged Point and Hills Point.

Approximately 34 per cent of the area covered by water in the territory under discussion has been affected by erosion or by sedimentation. Of this portion about 80 per cent, or approximately 26 per cent of the total area under water, has been subjected to scouring during the 52-year interval from 1848 to 1900 . It appears from a study of profiles and contours that the vertical elements in the areas of erosion and in the areas of sedimentation are approximately equal. Now, inasmuch as but 20 per cent of the area subject to change showed shoaling while 80 per cent showed scouring, and as the vertical element is approximately the same in each case, it becomes evident that the equivalent of at least 60 per cent of the sediments affected in the area must have been carried farther down the bay. The areas subjected to erosion aggregate 35 square miles and those subjected to sedimentation 9 square miles, making an excess of 26 square miles eroded. By taking $1 \frac{1}{2}$ feet as a reasonable average for the amount of vertical change, the total quantity carried out of the area and down the bay would approximate 0.007 cubic mile. Of course, no estimate is possible as to the amount transported through this area from points beyond its borders. However, it is apparent that a study of the entire bay would yield interesting data on the amounts of material eroded and deposited in different portions of it. If to such data could be added an estimate of the amount of sediment carried past any point in the bay during the 52-year interval, an approximate estimate could be made of the total land waste of the basins drained by the tributary streams above this point. Such a result would be of fundamental importance to geologists in the consideration of the phenomena of denudation. 


\section{SUMMARY.}

The quantitative results of the study can best be presented by the following table:

Results of erosion at mouth of Choptank River.

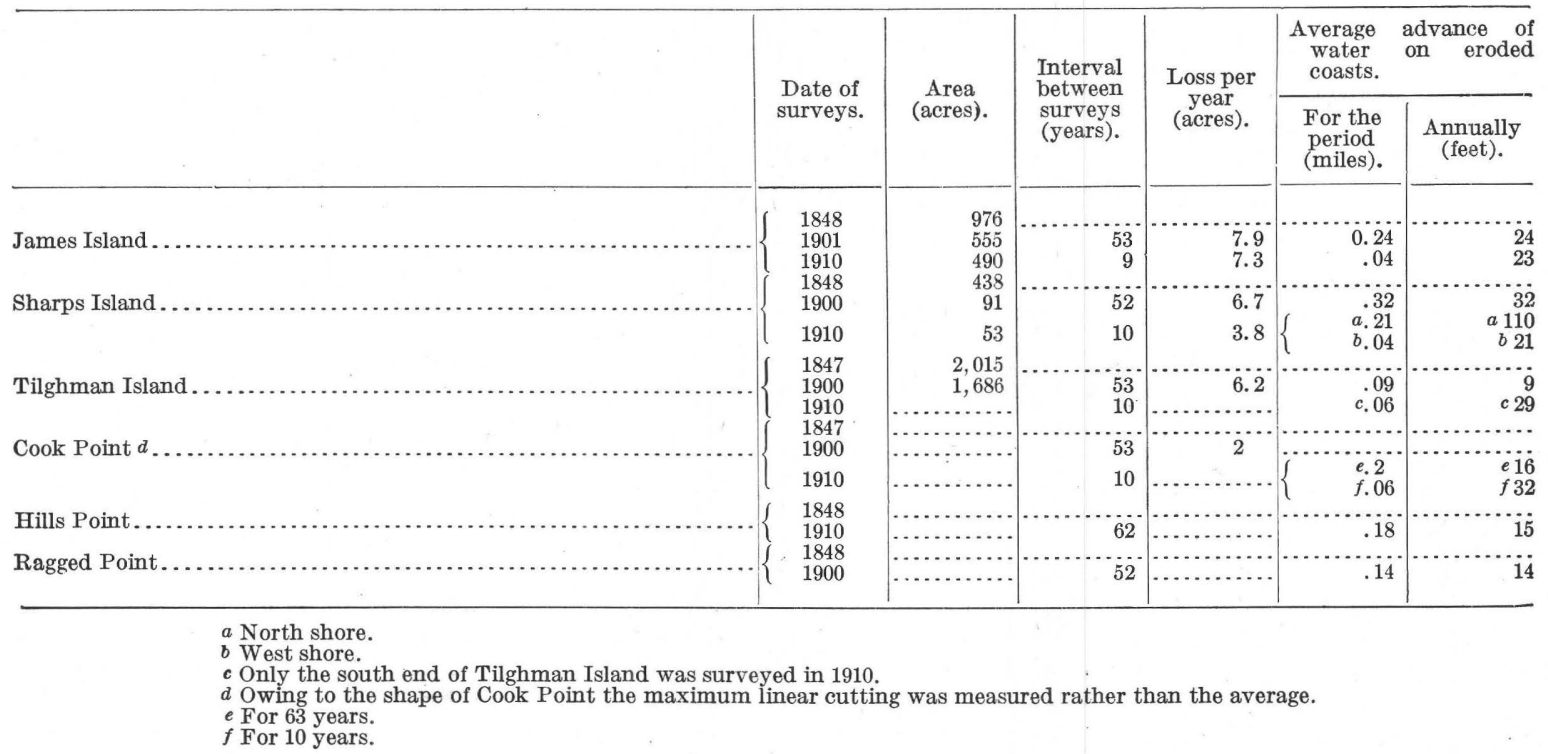

The most interesting feature of the study is the rapid destruction of the three islands. Sharps Island is disappearing most rapidly and will probably be entirely effaced before 1950 . The remarkable rate of cutting during the last 10 years on the north end of this island, amounting to 110 feet a year, is worthy of note. Observation shows that practically all the erosion has been on the west and north sides of the islands; that is, on the shores which are most open to the attack of the southerly bay currents and the westerly winds and their waves. In general the cutting has been greatest along the shores having low scarps made up of the clays and marls of the Talbot formation and least along those of the low-lying tidal marshes. For this reason the land now being formed will in many places outlive the older and higher portions. Most of the projecting points within the entrance to the Choptank show considerable change, although much less than the shores of the bay proper. No building up of the land is going on within the area studied, although farther south extensive delta deposits are being laid down.

A study of the submarine changes shows rather extensive scouring along the eastern shore of the bay proper and less extensive though equally intensive shoaling at places within the river mouth. The equivalent of approximately 60 per cent of the total amount of the sediments subject to change in the area is carried farther down the bay. A very rough estimate of the quantity of material carried away from the area is 0.007 cubic mile, but owing to the fact that this material comes from several different basins and that the amount of sediment transported through the area is unknown no idea as to the rate of land waste could be obtained.

In conclusion, while the present work should be regarded only as a test investigation of the erosion and sedimentation in Chesapeake Bay, it is demonstrated by the comparison of the two surveys of 1848 and 1900 that very significant changes both in the topography and in the hydrography of the region have taken place. Although the data here set forth are chiefly of local importance, it is hoped that the study may suggest certain methods that are applicable to a complete study of the bay. Such a study of the changes during an interval of over 50 years would present some idea as to the land connections and distribution not only of the past but likewise of the future. It would also give quantitative data on the rate of erosion and of sedimentation and, if carried far enough, should furnish new and significant data on the rate of land waste in the surrounding basins. Finally, if the study of this small area shall lead to a more extensive investigation as to the quantitative relations of these fundamental geologic processes, the purpose of the work will have been fulfilled. 